\title{
THE IMPACT OF SPORTS DIPLOMACY ON IMPROVING KOSOVO'S INTERNATIONAL IMAGE
}

\author{
Rinor REXHEPI (iD) $1 *$ \\ Vigan SAHITI (iD) 2 \\ 1 Universum College, Faculty of Diplomacy, rexhepirinor@hotmail.com *Correspondent Author. \\ 2 Universum College, Faculty of Diplomacy, vigansahitil@gmail.com
}

\author{
Article history: \\ Submission 29 March 2021 \\ Revision 11 June 2021 \\ Accepted 25 July 2021 \\ Available online 31 August 2021
}

Keywords:
Public Diplomacy,
Sports Diplomacy,
Kosovo,
Sports,
International Image.

DOI:

https://doi.org/10.32936/pssi.v5i2.247

\begin{abstract}
A b s t r a c t
Public diplomacy which is part of soft power is a branch of diplomacy which has recently taken place and importance in the agendas of large and small states. This segment of diplomacy includes a series of methods and maneuvers which bring positive results to the country it uses and promotes for its own interests. Sports diplomacy is an important dimension of a country's public diplomacy, which has an important and influential role. Different countries aim to use sports diplomacy in the most effective way in favor and profit of their country, and one of these countries is the state of Kosovo. During our work we have tried to present the impact of Kosovo sports diplomacy and its role in improving the international image. Through descriptive, comparative, analytical methods as well as through interviews we have tried to shed light on how much sports diplomacy has influenced the improvement of Kosovo's international image. With the method of interviews, we have interviewed 3 experts in sports diplomacy, and we have analyzed these interviews by implementing the comparison with materials and scientific facts which are related to public diplomacy, with an emphasis on sports diplomacy. In conclusion, we can say that sports diplomacy in Kosovo should be given great importance in order to achieve greater results. Kosovo and its competent institutions need to develop specific strategies and investments for its sports diplomacy.
\end{abstract}

\section{Introduction}

Sports diplomacy is an important dimension of a country's public diplomacy, which has an important and influential role. Different countries aim to use sports diplomacy in the most effective way for the benefit and profit of their country. Through sports diplomacy, states can improve their image in the international arena and reveal the positive aspects that influence the creation of the perception of foreign opinion in relation to the lobbying state. Through this paper we have tried to elaborate the impact of sports diplomacy of Kosovo in improving the image of the country in the international arena. Given that Kosovo is considered and is a new state in the international arena, obviously any method of improving the image is welcome.

Our study aims to elaborate Kosovo sports diplomacy and its difficulties to be promoted in the international arena, given the small capacity of the country which often directly affects the lack of further results of sports diplomacy and all areas of diplomacy. Despite all the difficulties that accompany the state of Kosovo for its appearance through public diplomacy with an emphasis on sports, there are athletes and events which indirectly from other pedestals have represented the state of Kosovo.

During this study we have tried to present the importance of sports diplomacy of a country with an emphasis on Kosovo, and we have tried to show the impact that sports diplomacy has had on improving the image of Kosovo in the international arena, we have interconnected elaborated concrete literature regarding sports diplomacy and the case of Kosovo. Furthermore, we have brought the impact of sports diplomacy on the image of Kosovo through interviews of individuals competent for this issue and who have directly and indirectly influenced these developments and the course of events that are in the vortex of public diplomacy, especially sports diplomacy. 


\section{Literature Review}

Public diplomacy is a branch of traditional diplomacy that is part of the soft power which is used more and more every day in certain fields, for certain interests of different states, small or large. Soft power is a strong shaper of foreign public opinion and is a cheaper option than force (Ikenberry \& Nye, 2004). Many different scholars and theorists define public diplomacy in different forms and consider that the key elements for public diplomacy are: foreign policy, culture, national values and many different actors and different public factors (Mekaj, 2020). Public diplomacy is not done just for today; it must be planned to yield results that are expected to be seen in the future. It takes time to see its results, and they are not always measurable (Olins, 2005) Sports diplomacy is the use of sports activities by a state to improve its image, to relax tense relations or any other way to realize foreign interests. The use of the successes of athletes, for the sake of the image and prestige of the state spread after the Second World War, initially mainly from the Soviet Union, from the 70 s also from developed western countries (Macintosh and Hawes, 1994). Sports activities are followed by a very large number of spectators, either directly in stadiums or through the media. This makes them important forums where states aim to act to improve their image (Fazliu. 2015).

The case of ping-pong diplomacy is well known, a case that served to improve Sino-US relations during 1971. The United States team played friendly matches with the Chinese team, visited the Great Wall and the Summer Palace outside Beijing, met with Chinese students and workers. A year later, Chinese players traveled to the United States, playing a series of friendly matches in front of enthusiastic audiences (Usa Department of State, 2006).

Sports diplomacy is also an important dimension of a country's public diplomacy. The successful ones, the talents, the champions, are the main object of the sports media, but also of the generalist media. When such a talent turns out to be successful, the media further spreads its success to the audience, while the athlete is the representative of a country (Salihu, 2013). Small states often aim for certain strategies, with low costs as well as the best possible profits (Mekaj, 2020). The concrete case of success through sports diplomacy is Singapore. The strategy of this state government to strengthen its profile in major international sporting events was supported by a focus on seven priority sports, including table tennis, badminton and sailing, and this strategy brought it great success by winning medals in these sports (Houlihan, Barrie and Zheng, Jinming, 2014).

Kosovo, as a small country, has the potential to achieve its diplomatic objectives through certain sports and arts in which it is more successful. Kosovo does not have financial resources available, it must find lower cost ways to present the country in the international arena (Haxhimehmeti, 2015). The "diplomatic assets" that Kosovo has with its people all over the world, but also within Kosovo, enables this new state to develop on a large scale public diplomacy, culture, sports, with figures like Majlinda Kelmendi, Xherdan Shaqiri, Granit Xhaka, Vedat Muriçi, Dua Lipa, Rita Ora, etc. Normally, all this can be achieved by drafting state strategies through relevant institutions, which would promote the cultural / artistic and sports values of this country (Ngadhnjim Brovina, Dritero Arifi, Fjollë Nuhiu, 2020). Many well-known athletes serve as a role model for world youth, at one point they are seen as a representative of their country's public diplomacy (Sancak, 2015).

Thus, the Republic of Kosovo through its athletes who have displayed its image in international arenas have had impacts on improving and creating the image of Kosovo. The numerous successes of the talents of the Republic of Kosovo have influenced the raising of the flag of Kosovo in the international arenas. Below we will elaborate on some cases of Kosovo's diplomatic victories through sport. The focus of this paper will be the two sports that best represented Kosovo abroad, Judo and football.

Great success in sports was brought to Kosovo by the judo club "IPPON" which is led by coach Driton Kuka, and in its composition has talented judokas such as: Majlinda Kelmendi, Nora Gjakova, Distria Krasniqi and Akil Gjakova. All these judokas have won various medals in international competitions under the emblem of the state of Kosovo, directly affecting the improvement of Kosovo's image.

Majlinda Kelmendi can be called the ambassador of Kosovo, who has done sports diplomacy continuously. Kelmendi in 2009 won the gold medal at the World Junior Championships in Paris, in 2010 he came fifth at the World Junior Championships in Morocco, ninth at the world at the World Judo Championships in Tokyo, Majlinda won these medals by competing for Albania, Kosovo was admitted to the International Olympic Committee in 2014; while debuting in 2016 with eight athletes. In February 2016, Majlinda Klmendi won the gold medal at the Grand Slam Paris, making it the third consecutive title after winning in 2014 and 2015 (representing Albania at the time). Two months later, she won a gold medal at the European Judo Championships in Kazan, Russia (www judoinside,2016). While the most important event for Kosovo sports diplomacy is the announcement of Majlinda's victory in Russia. This event is special as Kosovo participated in competitions that took place in one of the countries most opposed to Kosovo's independence and subjectivity. 
Kosovo in these competitions was represented with all the symbols (flag and anthem) equal to all other countries; marking an extraordinary success in the field of diplomacy through sport. In addition to this success, Majlinda Kelmendi is a world champion several times in: World Championships Rio de Janeiro 2013, World Championships Chelyabinsk 2014, World Championships Budapest 2017, World Championships Tokyo 2019 (Judoinside, 2020).

Kosovo has some talents who have been successful in football teams across Europe. The peculiarity of footballers is that not only do they not hide their Albanian identity from Kosovo, but at the same time they constantly seek to show it, to talk about Kosovo, as is the case of footballer Xherdan Shaqiri born in Gjilan (1991), but emigrated to Switzerland. In 2013, he played for the Bayern Munich team and for the Swiss national team (Salihu, 2015). In the European Champions Cup final, on May 25, 2013, world televisions fixed Xherdan Shaqiri who leads the cup acquired by Bayern covered with a tailored flag together, that of Switzerland and Kosovo. He immediately after the end of the match was on the happy with the flag of Kosovo (and Switzerland) at the Wembley Stadium of London where the Finals was held (Sinani, 2015).

In 2016, the mission of the Football Federation of Kosovo was completed. Kosovo is the 210th member of FIFA. FFK received 141 votes for membership, out of 164 valid votes in the 66th FIFA Congress. In the same year, Kosovo was admitted to UEFA. This has influenced the many successes of Kosovo footballers representing Kosovo in the international arena. Since then, Kosovo has hosted many football matches as guests in different countries where the state of Kosovo was promoted in those countries as well as in international media such as: BBC, $\mathrm{CNN}$, The Guardian, etc. The Guardian newspaper wrote: Kosovo was accepted as a member of UEFA, becoming the 55th member of this body of European football, despite strong opposition from Serbia (The Guardian, 2016).

Judo started by participating in sports competitions with countries that do not know us, football also continued. In March 2021, the representative of Kosovo in football met Spain in the qualifications for the World Championship "Qatar 2022". Spain does not recognize Kosovo's independence and is one of the main states that opposes Kosovo's subjectivity. Although Spain initially stated that it would not accept Kosovo playing against them with its flag, anthem and coat of arms, it was forced by FIFA to accept Kosovo to play like any other country, represented by flag and anthem. The Spanish media considered this decision of FIFA as a diplomatic victory of Kosovo. (Elpedrico.com, 2021). According to the Spanish media, all world media wrote about this match, which also considered this match as a diplomatic triumph of Kosovo. (Euronews.com, 2021).

So, the successes of Kosovo athletes have had an impact on improving the image of Kosovo in the international arena. The use of public diplomacy and its segment of sports diplomacy is very necessary for the state of Kosovo. For these successes, all the credit goes to the athletes, while state institutions have contributed little. The state of Kosovo has paid attention to sports only through the Ministry of Culture, Youth and Sports where it is emphasized that: The Department of Sports has supported and assisted the development of numerous sports activities, through which it aims to contribute to the substantive organization, staff development, membership and licensing of Kosovar sports in international federations, involvement of all in sports activities, regardless of nationality., race and religious affiliation (Republic of Kosovo Ministry of Culture, 2020).

Regardless of whether the state has given support to these individuals or not, their achievements have served the interest of promoting and building the image of Kosovo, much more than any government effort to improve the image (Hajdari, 2019). In the case of Kosovo, sport can play a special and increasingly important role in the diplomatic efforts of the new state and contested towards full international recognition (Brentin \& Tregoures, 2016).

\section{Methodology}

The methodology used to carry out the work is through primary and secondary materials based on scientific facts. Also, through interviews conducted with experts in the field and sports professionals, who are directly involved in sports in Kosovo. Through the interviews it was intended to know as concretely as possible the result of the influence of diplomacy and sports activities in improving the image of Kosovo in the international arena. Then we described the interviews, as well as made the final interpretation in an attempt to extract the most concrete results, as well as in order to confirm the hypotheses raised.

\section{Hypotheses 1}

H1: Sports diplomacy can be an important factor in improving a country's image internationally.

H0: Sports diplomacy cannot be an important factor in improving the image of a country internationally

\section{Hypotheses 2}

H2: Sports diplomacy has improved the image of Kosovo in the international arena.

H02: Sports diplomacy has not improved Kosovo's image in the international arena. 


\section{Interviews}

Table 1. Analysis of interviews with two professors of public diplomacy, and a sports trainer

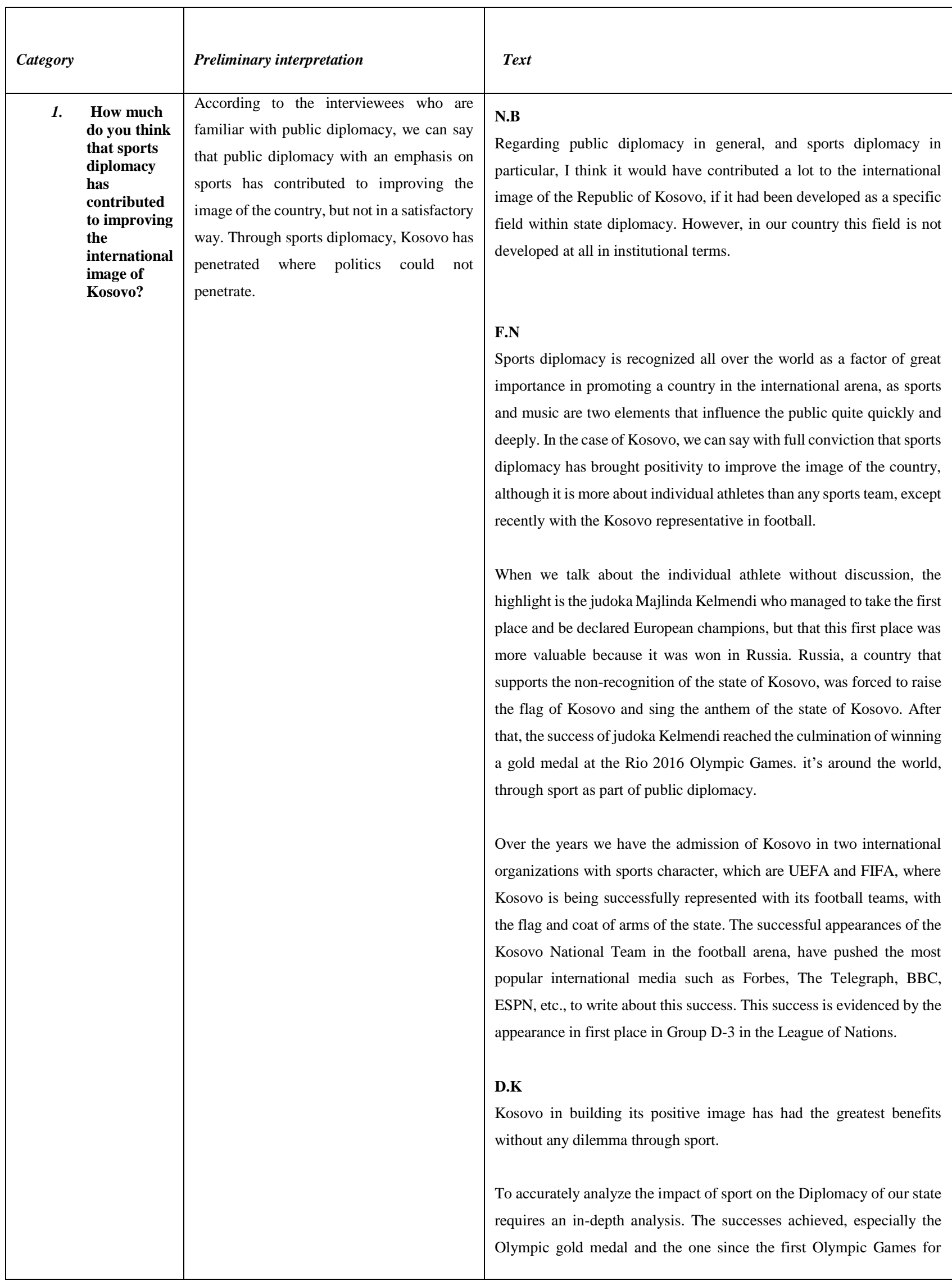




\begin{tabular}{|c|c|c|c|}
\hline & & & $\begin{array}{l}\text { Kosovo, has put its main protagonist Majlinda Kelmendi at the top of all } \\
\text { world media. } \\
\text { To assess the impact of sports in Diplomacy requires a very serious } \\
\text { approach which in the future should be an active part of the Diplomacy } \\
\text { of our country, because so far no step has been taken to use Sports } \\
\text { Diplomacy to promote the state. }\end{array}$ \\
\hline 2. & $\begin{array}{l}\text { Have the } \\
\text { institutions } \\
\text { of the } \\
\text { Republic of } \\
\text { Kosovo } \\
\text { sufficiently } \\
\text { supported } \\
\text { sports } \\
\text { diplomacy? }\end{array}$ & $\begin{array}{l}\text { According to experts in the field who were } \\
\text { interviewed, it can be understood that } \\
\text { Kosovo institutions, knowing the importance } \\
\text { of sports diplomacy, have done little in this } \\
\text { regard. Institutional support in all forms of } \\
\text { sports diplomacy has stagnated. }\end{array}$ & $\begin{array}{l}\text { N.B } \\
\text { As I mentioned in the previous question, sports diplomacy is not } \\
\text { developed in our country, although the resources for the development of } \\
\text { this field are not lacking, but there is a lack of institutional support and } \\
\text { state strategy for the development of public diplomacy in general and } \\
\text { sports diplomacy in particular. It was intended to do something in this } \\
\text { regard, but there is nothing concrete and specific, referring to the } \\
\text { institutions that should lead this field. I think that our institutions should } \\
\text { not support this field, but should have part of it, i.e. part of foreign } \\
\text { policy. } \\
\text { F.N } \\
\text { The state institutions of the country, knowing the importance of sports } \\
\text { diplomacy, have done almost nothing in this regard. In general, the } \\
\text { institutions are not seriously committed to investing and developing } \\
\text { diplomacy as a whole, especially sports and culture, so we cannot say } \\
\text { that it has had any impact that is worth noting. } \\
\text { D.K } \\
\text { The only support is that some athletes have already been provided with } \\
\text { diplomatic passports, but serious initiative on this issue so far concretely } \\
\text { lacks, yet. } \\
\text { Former Minister Stublla Harradine had started to build something in this } \\
\text { direction but it was concretely realized as the cause of the fall of the } \\
\text { Government. } \\
\text { So far no concrete action has taken place for Sports Diplomacy. }\end{array}$ \\
\hline & $\begin{array}{l}\text { What } \\
\text { actions } \\
\text { should the } \\
\text { state of } \\
\text { Kosovo take } \\
\text { to help } \\
\text { sports } \\
\text { diplomacy? }\end{array}$ & $\begin{array}{l}\text { According to the acknowledgments that have } \\
\text { been interviewed by the actions that Kosovo } \\
\text { should have to help sports diplomacy are: } \\
\text { Kosovo should pay attention to greatly } \\
\text { supporting sports diplomacy in order to } \\
\text { influence its influence on improving } \\
\text { Kosovo's international image; Kosovo } \\
\text { should form a special department within the } \\
\text { Ministry of Foreign Affairs, which would } \\
\text { deal with sports. This department should be } \\
\text { led by an athlete who in coordination with the } \\
\text { Minister of Foreign Affairs would draft } \\
\text { strategies on how to use the sport as public } \\
\text { diplomacy. }\end{array}$ & $\begin{array}{l}\text { N.B } \\
\text { The Republic of Kosovo as a new state, without military power and } \\
\text { economic capacities that would affect other countries, has diplomacy as } \\
\text { its only tool and its main "card", to be more precise, public diplomacy. } \\
\text { Normally, if this field is developed as the main "weapon" of our } \\
\text { country's foreign policy, our image as a country will improve } \\
\text { significantly, taking into account the national wealth we have (Kosovo } \\
\text { Representative, Majlinda Kelmendi, etc.) and that belong to and could } \\
\text { help in the development of public diplomacy (sports diplomacy, cultural } \\
\text { diplomacy, etc.). Eminent figures in the sports aspect, in the } \\
\text { international arena, who are of Kosovo origin, should become part of the } \\
\text { medium-term and long-term strategy of sports diplomacy. }\end{array}$ \\
\hline
\end{tabular}




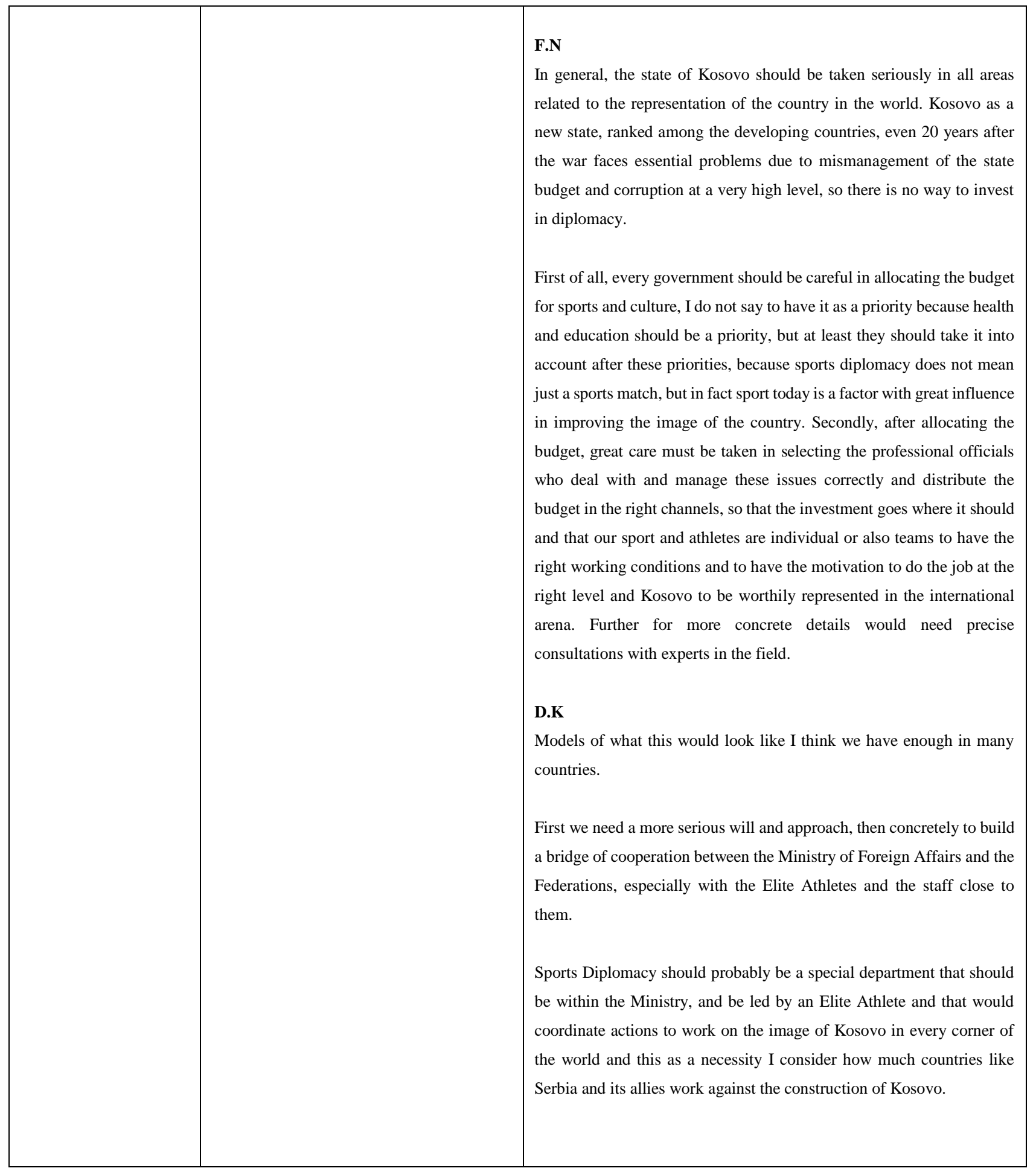

\section{Interpretation of Interviews}

\subsection{How Much Sports Diplomacy as}

\section{Contributed to Improving the International}

Image of Kosovo?

Kosovo as a small country with limited capacities has achieved profits through public diplomacy in most cases. Sports diplomacy all over the world is recognized as a factor of great importance in promoting a country in the international arena, because sports and music are two elements which create quite fast and deep influence in the public. In the case of Kosovo, we can say with full conviction that sports diplomacy has brought positivity to improve the image of the country, although it is more about an individual athlete than a sports team, except recently with the representative of Kosovo in football.

Over the years we have the admission of Kosovo in two international organizations with sporting characters, which are 
UEFA and FIFA, where Kosovo is being successfully represented with its football teams, with the flag and coat of arms of the state. The brilliant performances of the Kosovo National Team in the football arena, have pushed the most popular international media such as Forbes, The Telegraph, BBC, ESPN, etc., to write about this success.

Since the internationalization of sports and Kosovo's membership in international sports federations, Kosovo has been promoted quite well in the international arena. Through sports diplomacy, Kosovo has deported where politics could not deport. Kosovo sports diplomacy, although not at the right level, has seen positive results from its athletes in international arenas, displaying the image of Kosovo in the international arena, as well as directly and indirectly influencing the improvement of Kosovo's image.

\subsection{Kosovo Institutional Support to Sports Diplomacy}

Sports diplomacy is not developed in our country, although the resources for the development of this field are not lacking, but there is a lack of institutional support and state strategy for the development of public diplomacy in general, and sports diplomacy in particular. The state institutions of the country, knowing the importance of sports diplomacy, have done almost very little in this regard. Kosovo institutions have not done enough for sports and have not helped us to internationalize even more, except for the announcement of athletes as honorary ambassador by the state of Kosovo. Seeing the impact on improving the image of Kosovar athletes is an unforgivable thing how the state of Kosovo has paid so little attention to sports diplomacy.

\subsection{What Action Should the State of Kosovo}

\section{Take to Help Sports Diplomacy?}

Given the capacities that the Republic of Kosovo enjoys, it should focus on a certain strategy and field of diplomacy, in order to improve its image in the international arena.

Seeing the importance of sports diplomacy and the successes it has brought to Kosovo, Kosovo should invest more in improving the conditions of athletes, in training halls, gyms, where Kosovar athletes could be trained at the same level as international athletes. . In order to be better represented through sports, Kosovo needs to hire sports diplomacy experts who will draft strategies on how to make better use of sports diplomacy.

A public diplomacy department should be activated within the Ministry of Foreign Affairs, which should manage and operate public diplomacy. The allocation of the budget allocated for sports diplomacy as well as for the field of sports should be greater by the state of Kosovo. Normally, if this field will be developed as an important tool of our country's foreign policy, our image as a country will significantly improve, given the national wealth we have (Kosovo Representative, Majlinda Kelmendi, etc.) which are part of, and could help in the development of public diplomacy (sports diplomacy, cultural diplomacy, etc.). So there are a number of challenges and strategies that the state of Kosovo must use to benefit from sports diplomacy.

\section{Conclusions}

The public diplomacy of a country is of great importance where it includes a series of segments, one of these segments of great importance is sports diplomacy. Kosovo sports diplomacy has indirectly contributed to improving Kosovo's image in the international arena. In our paper we have presented the importance of sports diplomacy for Kosovo, as well as the impact of using this form of diplomacy to achieve the goal of improving the country's image at the international level.

The scientific literature used and researched, as well as the three participants in our interviews who are directly and indirectly involved in Kosovo sports diplomacy, have guided us on a clear path to conclude that Kosovo sports diplomacy does not is properly developed, and not given the proper attention. We can also conclude that athletes and sports diplomacy of Kosovo athletes and originally from Kosovo has directly and indirectly influenced the improvement of Kosovo's image in the international arena, where it is worth mentioning, Xherdan Shaqiri, Majlinda Kelmendi and the representative of Kosovo in football, etc.

Also, the verification of the hypotheses raised was done based on facts, scientific arguments and based on the interviews conducted. The hypothesis that: A). " Sports diplomacy can be an important factor in improving the image of a country in the international arena. " Has been proven based on historical cases such as table tennis diplomacy (China-US) and baseball (USA-Cuba), as well as in the case of Kosovo, where there has clearly been an improvement in the international arena in the image of Kosovo as a result of athletes who are from Kosovo. Since the internationalization of sports and Kosovo's membership in international sports federations, Kosovo has been promoted quite well in the international arena. Through sports diplomacy, Kosovo has overcome prejudices and has begun to rebuild its image, damaged by the propaganda of unrecognized states. While the other hypothesis: B). "Sports diplomacy has influenced the improvement of Kosovo's image at the international level." This hypothesis has also been confirmed based on clear facts and 
results that Kosovo has had. Over the years we have the admission of Kosovo in two international organizations with sporting characters, which are UEFA and FIFA, where Kosovo is being successfully represented with its football teams, with the flag and coat of arms of the state. The successful appearances of the Kosovo National Team in the sport of football, have pushed the most popular international media such as: BBC, CNN, New York Times, Bild, etc., to write about this success. Separately, the success of Majlinda Kelmendi in Russia and the Football Representative in Spain, can be considered concrete facts in confirming this hypothesis.

Based on what we have elaborated throughout this study we can recommend that, given the importance of sports diplomacy and the successes it has brought to Kosovo, Kosovo should pay special attention to sports by taking examples of countries that successfully have used sport to achieve the objectives of sports diplomacy. For this, Kosovo must engage international experts to draft sports strategies that through sport remove the prejudices of international opposition. An example of the success of this strategy is the state of Singapore which has drafted concrete plans for the advancement of sports diplomacy, where Singapore has set some priority sports such as: ping-pong, badminton and sailing, these sports are given priority in financial support for improving sports conditions as well as athletes who triumph in international championships are given rewards to motivate them to bring new successes. We consider that Kosovo should follow the example of Singapore by declaring judo a sport with special priority and provide financial support for the improvement of sports conditions, as well as reward athletes in this way. Kosovo athletes would be stimulated to rich with many successes. And these successes would even better promote the state of Kosovo abroad through sports diplomacy.

\section{References}

1. Brentin, D., \& Tregoures, L. (2016). Entering Through the Sport's Door? Kosovo's Sport Diplomatic Endeavours Towards International Recognition. Diplomacy \& Statecraft, 27(2), 360378. https://doi.org/10.1080/09592296.2016.1169799

2. Brovina, N., Arifi, D., \& Nuhiu, F. (2020). UBT International Conference. Public diplomacy and the case of Kosovo (9th ed., pp. 21-27). Lipjan, Kosovo; UBT. Available at https://knowledgecenter.ubtuni.net/conference/2020/all events/199/?utm source =knowledgecenter.ubtuni.net $\% 2$ Fconference $\% 2 F 2020 \% 2$ Fall events $\% 2 F 1$ 99\&utm medium=PDF\&utm campaign $=$ PDFCover $\underline{\text { Pages }}$
3. Fazliu, F. (2015). Diplomacia Publike. Instituti për Studime Politike dhe Ndërkombëtare (ISPN).

4. Garcia, A. (2021, March 30). Malabares diplomáticos para el España-Kosovo. Elperiodico. Available at https://www.elperiodico.com/es/deportes/20210330/s alvoconducto-diplomatico-espana-kosovo-11627234

5. The Guardian. (2016, May 3). Kosovo accepted as member of UEFA after Congress vote. The Guardian. Available at https://www.theguardian.com/football/2016/may/03/ kosovo-accepted-uefa-member-vote-congress

6. Hajdari, L. (2019). The role of sports and music in public diplomacy: the case of Kosovo. Przegląd Europejski, 3, 189-203. https://doi.org/10.5604/01.3001.0013.5849

7. Haxhimehmeti, M. A. G. (2015). "The Soft Power" of Small Countries: Kosovo Challenges and Potentials based on the Experience of Switzerland and Slovenia. ILIRIA International Review, 5(1), 337. https://doi.org/10.21113/iir.v5i1.23

8. Holroyd, M. (2021, March 12). Spain vs. Kosovo World Cup qualifier to go ahead with flags \& anthems. Euronews. Available at https://www.euronews.com/2021/03/12/spain-vskosovo-world-cup-qualifier-to-go-ahead-with-flagsand-anthems

9. Houlihan, B., \& Zheng, J. (2014). Small states: sport and politics at the margin. International Journal of Sport Policy and Politics, 7(3), 329-344. https://doi.org/10.1080/19406940.2014.959032

10. IJF, M. P.-. (2016, February 6). Majlinda Kelmendi claims third title in Paris. JudoInside, the latest judo results, news, photos, videos and stats. Available at https://www.judoinside.com/news/1108/majlinda Ke lmendi claims third title in Paris

11. Ikenberry, G. J., \& Nye, J. S. (2004). Soft Power: The Means to Success in World Politics. Foreign Affairs, 83(3), 136. https://doi.org/10.2307/20033985

12. Macintosh, D., \& Hawes, M. K. (1994). Sport and Canadian diplomacy. McGill-Queen's University Press.

13. Majlinda Kelmendi, Judoka. JudoInside. (2020). Available at https://www.judoinside.com/judoka/42942/Majlinda _Kelmendi/judo-career

14. Mekaj, G. (2020). Public Diplomacy of small states: case of Kosovo. ILIRIA International Review, 10(2). https://doi.org/10.21113/iir.v10i2 
15. Olins, W. (2005). Making a National Brand. The New Public Diplomacy, 169-179.

https://doi.org/10.1057/9780230554931_9

16. Promovimi kulturor. Ministria e Kulturës, Rinisë dhe Sportit. (n.d.). Available at https://www.mkrs-

ks.org/?page $=1 \% 2 \mathrm{C} 35$

17. Salihu, H. (2013). (dissertation). Komunikimi ne

Diplomacine Publike. Available at

http://www.doktoratura.unitir.edu.al/wp-

content/uploads/2014/03/Doktoratura-Hasan-Saliu-

Fakulteti-i-Histori-Filologjise-Departamenti-i-

Gazetarise.pdf

18. Sancak, K. (2015). Dış politikada bir etki aracı olarak yumuşak güç: Türkiye'nin yumuşak gücünün analizi ve Azerbaycan üzerindeki yumuşak güç kapasitesinin değerlendirilmesi (dissertation). Available at https://scholar.google.com.tr/scholar?hl=tr\&as_sdt=0 $\% 2 \mathrm{C} 5 \&$ cluster $=5378320028713272816 \& \mathrm{fbclid}=\mathrm{IwA}$ R3HK4fOGWDP3kOgITEZPa4F5BsGuxSAB_Z_aJ iu0zyBeTTA4na6YsqFPC0\#d=gs_qabs\&u=\%23p\%3 D8MXSD5Kho0oJ

19. Sinani, R. (2015). Diaspora as a Communicating Actor in Public Diplomacy Compared to Public Government Diplomacy in the Case of Kosovo. Academic Journal of Interdisciplinary Studies. https://doi.org/10.5901/ajis.2015.v4n2p269

20. U.S. Department of State. (2021, April 9). Ping Pong Diplomacy - National Museum of American Diplomacy. U.S. Department of State. Available at https://diplomacy.state.gov/u-s-diplomacystories/ping-pong-diplomacy/ 